\title{
ゴルバチョフ海軍大軍拡の戦略理論的分析
}

\section{1. はじめに一矛盾と嘘の存在}

ゴルバチョフ書記長の下のソ連「軍縮」には, 従来のソ連にはない本格的なものがある。欧州な らびにモンゴルからの地上兵力の削减・撤兵はそ の最も影著なものであろう。前者については 89 年 5 月 23 日のW P 約 6 万輛の戦車のうち約 4 万 轌削减をC F E に提案した。「6 $6 \%$ 軍縮」であ る。後者については, ゴルバチョフ就任以前には ソ連地上軍は 5 ケ師団駐兵していたが，その 80 \%（４ケ師団）が 1991 年までに削减される。

核戦力についても, 地上配備の I N F (中距離 核戦力）の完全廃棄の米ソ条約の締結が1987 年 12 月であったし, 戦略核戦力の「50\%削減」が 1990 年中に米り間で合意される。化学兵器に ついても条件つきながら今世紀中に米ソが基本的 に全廃することでの調印がなされた。（1990年 6 月 1 日, (ワシントン)。

このため,ゴルバチョフ体制下のソ連の「軍縮」 について,なんらの留保もなく,それが実像である かのように西側では広く認識されている。果たし てそうであろうか。なぜなら, ソ連の真実の軍事 政策は，このようないくつかの事実を以て短兵急 に結論づけられるほど単純ではない。

ゴルバチョフ「軍縮」がその本質において西側 的な意味における“軍縮”であれば, 次のような 矛盾や虚偽がなぜ存在するのであろうか。

一 欧州やモンゴルから主として地上兵力の削 减をしながら逆に日本周辺では海空兵力の強化を している。

三 戦車の大巾な撤退をしながら, 戦車 $(\mathrm{T}$ 80 )の新規生産量は増大しているし新型戦車 （F S T ）の研究開発は着実に進められている。

三 海軍艦艇の大型化・高性能化をはかる新規 分の建造ペースは, 極端な増強傾向を示している。

四「軍縮」しているのに, またあれほどの軍
筑波大学 中 八 洋

縮の“宣言”がありながら，軍事支出は着実に増 大している。なお,ソ連では兵器の価格がないた め軍事費の積算は実際にはできない。ソ連史上初 の公表という鳴り物入で“宣伝(プロパガンダ) ” されたゴルバチョフによる「773 億ルーブル」 （1989 年）は架空の数字にすぎないし，その 「1 $4.2 \%$ 削减」公約もなんら根拠もない。単な る宣厷である( 1989 年 5 月, 注 1 )。

西側では，このような矛盾の存在や虚構の宣层 に対して, やみくもに無視したり根拠のない思い つきの解釈を加えようとするが，これらの解明こ そゴルバチョケ「軍縮」の真の狙いを明らかにす るものである。すなわち, 欧州軍縮と極東軍扗, 核軍縮と海軍軍払などは，ゴルバチョフの世界戦 略の下に精緶に策定されたものであって，いずれ も相互に矛盾すると考えるよりは整合したもので あると考えるべきである。

同様に, ゴルバチョフの下で事実としてなされ る軍縮と純粋な嘘による宣伝について, 遇然に生 じた矛盾ではなく一つの戦略の下から導かれたも のとすべきであろう。宣伝 (プロパガンダ)にし ろ, 演技にしろ, 事実と嘘を織りまぜた“half - truth”の手法がその対象（target）に所期 の錯覚 (誤認識)を最も効果的に与えうるもので ある。ゴルバチョフ「軍縮」に僅かでも明白な,

“軍拡”が含まれているのであれば,この「軍縮」 は西側の通念上の “軍縮”でなく, 他の戦略目標 を達成する手段としての「軍縮」であると結論す るのが正しくかつ妥当であろう。

\section{2.「ハートランド」の海軍力と侵略性}

世界最大の戦略縦深をもつユーラシア大陸の中 权（ハートランド）に位㨁し貿易依存度の低い ( 死活的な S L O C を必要としない) ソ連は，そ の国の防衛（ defens e) のためには外洋海軍力 
カ(ブルー・ネイビー) の保有は全く不要である。 他国のいかなる海軍力もこの「ハートランド」攻 撃能力が欠如しているからである。すなわち, ソ 連のシーパワー化が推進されているのであれば, その事実自体, ゴルバチョフのソ連が本質的な侵 略性を堅持しているのは余すところなく証明され たことになる。

ゴルバチョフ書記長の下でのソ連海軍の一大特 改は,フルー・ネイビーの中核をなす正式空母が ハイペースで建造されたことであった。プレジネ フが決意した排水量 6 万 5 千トンのトビリシ級一 番艦を就役に向かってその建造を続けただけでは ない (着工 83 年 11 月, 進水 85 年 12 月, 海 上公試 89 年 11 月, 注 2$)$ 。ゴルバチョフ自身 が二番艦と三番艦の着工を新たに命じている(そ れぞれ 85 年 12 月と 88 年 11 月)。この事実 は，ゴルバチョフが内に秘めているその侵略性を 暴く完全な証拠であろう。

主として侵略以外に用途のない, またり連経済 を破綻に導いてもなお強行してやめることのない， このゴルバチョフ下のソ連の空母機動部隊建造の 計画の遂行は, ゴルバチョフ下の党の検閲を経た ソ連の新しい海軍ドクトリンとも符号する。 88 年 10 月に出版されたゴルバチョフ監修の新著 『海軍一役割, 発展の方向, 戦闘任務 ( 運用)』 ( 注 3 ) では次のように定められている。

「空母は水上艦艇部隊の主要攻撃力であり, 制 海権の獲得, 艦載機による敵領土内の軍事目標・ 産業目標等への攻撃, 上陸部隊等に対する航空支 援がその任務である。（注 4 ）

「新思考」を標榜しながら海軍力の増強をする ゴルバチョフの意図を明らかにするのは, その政 権下における艦艇の新規着工を以前と比較すれば よい。例えば, 1985 年〜 88 年の 4 年間の駆 逐艦以上の水上艦艇の年平均の着工合計トン数は, フレジネフ書記長時代の 12 年間( ‘ 73 ‘ 84 年)に比して 約 1.5 倍である。後者の年平均は, 3.5 万トンに比して 5 万トンにも及ぶからである。 ところで, ゴルバチョフ政権下のソ連海軍の增 強の理由として, ソ連の海軍力が米国のそれに比 していまだ劣位にあり対等を目指しているからだ
との説が流布している。ずぶの素人特有の思い違 いであるかもしれないが，一部はソ連の軍払を無 批判に全面支持する親ソ系のソ連「専門家」によ る意図的プロパガンタであろう。これは, ソ連の 核軍拡を正当化したS A L T I 協定に対する批判 をつぶしたあとの 70 年代の親ソ系キャンペーン のやり方と全く同じである。ソ連が背後にあるプ ロパガンタと見てもよい。米ソ海軍力の優劣比較 には，戦略核戦力の優劣比較の方法は全く用をな さない。後者は, 他の軍事力と独立した兵器体系 であり，またグローバルな戦争の兵器である。一 方, 前者は, リージョナル戦闘の兵器でありまた 他の軍種と統合化されて使用されるものであるか らそのバランス算定の手法は極めて複雑となる。

かくして, 米ソ海軍力の比較は, 例えば, 日本 海やオホーツク海などの具体的な“特定の海域” 毎に論じられるべきものである。このいずれの海 でも，米ソ双方が公式に認めあっているように ( 注 5 )，ソ連海軍力の方がシー・コントロール を確立しておりその絶対的優位は摇るがない。 「米海軍優位」説は，単に素人の錯覚として一笑 にふすことのできない極めて危険な幻想でもある。 日本の安全保障の観点において, 米ソ海軍力バ ランスは“ソ連海軍優位”とするのが正しい。

\section{3. 米ソ核軍縮とソ連海軍力増強}

\section{一 ソ連の世界制覇への基本戦略}

このソ連の海軍増強とソ連の積極的な対米核軍 縮は，美事な整合をなしている。この双方の同時 達成こそ, ユーラシア大陸・アフリカ大陸の完全 制覇のための車の両輪的な基本戦略となるからて ある。米国の戦略核戦力とは, ソ連の侵略が隣接 の地への侵攻というその地理的有利に対抗できる 有効な兵力であると同時にソ連通常兵力によるユ ーラシア大陸周縁地の征服・占領の侵略行動を抑 止する機能をもつ。つまり，米国の核戦力とは， 一義的にはソ連の核戦力と対峙しているわけては ない。とすれば,ゴルバチョフが自らの戦略核戦 力を半堿する代償を払って米国の戦略核戦力の半 滅に成功すれば, それは米国の対ソ抑止力の一方 的半隇に他ならず, しかも地理的有理の状況の方 
ゴルバチョフ海運大軍拡の戦略理論的分析

は不変であるから, ソ連としてはより侵略し易く なる。すなわち, 米ソ核戦力の「低水準の均衡」

化は, ソ連の軍事的優位を必然的にもたらす(注6)。

1989 年 5 月のC F Eにおけるゴルバチョ フの大胆な戦車約 4 万輛削减提案は, 上記の “米国の戦略核戦力対り連の地上兵力”という軍 事バランスの基本構造を欧米の諸国が強く主張し 続けた成果でもあった。このため, この 89 年 5 月以降, ソ連の「軍縮」にトリックがないとの認 識が欧米に広く定着したのである。ゴルバチョフ 下でのソ連で T - 80 の生産は年平均 3400 轌に及ぶ (日本の陸上自衛隊は年僅か 56 筩)。 コルバチョフ以前の年平均 2800 輛を一層加速 している (注 7 )。

すなわち, ソ連はここ当分の間西欧への侵攻を 全く断念したことは明らかだが，将来に対しては その準備を継続している。そして，欧州の地にお いては「軍縮」の形をもって, 約 4 万輛の旧式で 老朽化した戦車の大規模な退役をなして, 将来こ れをT - 80 や新型のF S Tに総入れ替えをする であろうと想定しておくのが正しい。

\section{4. あとがき}

ソ連が東欧やモンゴル から地上兵力を撤収し “大退却”をなしていることは, ソ連帝国の縮小 をゴル゙チョフが選択したことを意味する。

しかし，ここで勘違いをしてはならないことが $2 つ$ つ。第 1 は, あくまでも, 退却とは退却であっ て, 敗北とは無関係である。かって, ナポレオンのロ シアお遠征軍は, この大退却したアレクサンドル 一世靡下のロシア軍に大反攻され逆に敗北した。 ロシア (ソ連)と中国にしかできない，この“大 退却の兵法”について西側は留意しておく必要が ある。

第 2 は, ソ連の民族問題も経済問題もその混乱 が永久に続くものではなくいずれ必ず片がつく。 この時, 単に暫定的に静止しているだけのソ連の あの巨大な軍事力が必ず動き出す。核兵器もなく (ソ連に比して) 微 々たる軍事力しかない日本は, 決して遠くはないこの時点を予想しておかねばな らない。

\section{【注】}

1. 米国はこの軍事費 773 億ルーフルについ て「ソ連軍のサイスからして, 非現実的で低すぎ る。西側推定のおおむ称半分である。」としてい る。

DoD, Soviet Military Power: Prospects for Change 1989, p. 32 . また, ゴルバチョフ下での軍事支出は実 質年率 $3 \%$ 増であり, 米国の国防費削减（'85 〜 88 年で $11 \%$ 減）と鋭い対照をなす。

2.『プラウタ』‘89年10月19日, 11 月 22 日, 「赤い星」 10 月 22 日。

3. 邦訳『ソビィエト海軍戦略』, 大場企画出 版, 1989 年 12 月。

4. 上掲書, 155 頁。

5. ソ連側の資料では, 『海軍論集』‘ 89 年 年 2 月号, 169 頁。米国側の資料では, 前掲 Soviei Military Power. p.116. なお、これに関して拙稿「偽りの平和時代の国家 安全保障」「国防』‘89月12月号，56 9 頁を参照のこと。

6. 把稿「軍備管理と核抑止の相剋」『国際政 治 90 号」‘8 9 年 3 月, $25 \sim 8$ 頁参照のこと。

7. 前揭 Soviei Military Power. p. 34 .

質問者：丹羽春喜

（質問）中川報告の主旨や分析結果は非常に妥 当だと思う。

(1) 西側自由経済陣営および日本は, 中川報告 で述べられたようなソ連の強力な布陣に対し て，どのような対策をとったらよいのか？ (長期的・中期的・短期的に）日本の「侵さ ず侵されず」という態勢は, ソ連をナーバス にすることはないと思う。

(2) ソ連艦隊の稼働率の低さは, 予算節約の意 味もあるのではないか？ また, ソ連の軍事 科学技術を軽視するのは危険ではないか?

(3) 西側自由主義陣営のトータルとしての総合 
戦力の数字については, それを 100 パーセン ト戦力」として計算することは妥当ではない のではないか? 西側諸国の協調行動や共同作 戦はおそらくギクシャクしてうまくいかない であろうからである。

\section{( 回答)}

(1) 日本は，中長期的には核保有を含む防衛力 の抜本的な強化こそが不可欠となるだろうと 考えます。ソ連が他国の軍事力に対して心底 では敬意の念を持つことは考虑してよいと思 います。

(2) 全く同意見です。

(3) 今後, 西側同盟は, NA T Oにしろ日米安 保にしろ, 着実に弱体化する方向に進むであ ろうから, 御趣旨の弱点がますます払大して いくことになると思います。

質問者：中沢孝之

(質問 )

(1) レジメp.18.の「社内検閲」の具体的例 を是非挙げて下さい。外信部長の職あるもの として知っておきたいのでよろしく。

(2) ソ連の世界制霸に関して基本的疑問を一つ。 難問山積で自分の国すら十分にコントロール できない連の指導者が他国 (日本を含めて) を侵略占領して，その国をコントロールでき るとは常識では考えられないか，いかが。自 国民を満足に食わせられないのに全人類的利 益を云々することはおこがましい一という 先生の論理をそのまま適用してみると, なお さら世界制覇論の根拠は乏しいと思われます。

\section{(回答)}

(1) 1986 年 4 月のワインバーガー長官の東 京での記者会見における，択捉島への（対日 用) 核搭載可能ミサイル配備という衝搫的な 一大重大二ュースがいくつかの新聞や T Vか ら完全に抹殺された具体的実例等に対して, ジャーナリスト自身こそが追跡調査して「社
内検閱」の実態を明らかにされるべきであろ うと思います。

(2) $1920 \sim 30$ 年代, 資本主義国の多くの 知識人がソ連について中沢部長と全く同じこ とを語っています。それが完全な誤りであっ たのはWW II 中のソ連の行動によって既に証 明済みです。 